\title{
Food Vending Characteristics and Students' Preferences for Food Vending Services: A Discrete Choice Experiment
}

\author{
Gilbert Abotisem Abiiro \\ (Corresponding author) \\ Department of Planning, University for Development Studies \\ Email: gabiiro@uds.edu.gh. \\ Emmanuel Kofi Gyan \\ Department of Governance and Development Management, \\ University for Development Studies

\section{Bernard Afiik Akanpabadai Akanbang} \\ Department of Planning, University for Development Studies \\ DOI//http://dx.doi.org/10.4314/gjds.v16i1.4
}

\begin{abstract}
There is limited understanding of the influence of multiple characteristics of food vending on students' preferences for vended food. This study assessed students' preferences and willingness to pay (WTP) for various characteristics of food vending service. A Discrete Choice Experiment (DCE) was administered to 585 students of the Wa Campus of the University for Development Studies, Ghana. The respondents were selected through multistage sampling. Data was collected using a structured experimental survey questionnaire. Six attributes (and attribute levels) were identified from a qualitative study and used to design the DCE: Food taste (natural vs. spicy), environmental sanitation (good vs. poor), vendor's personal hygiene (good vs. poor), customer relations (good vs. poor), vendors' location (far from vs. near to students) and price ( $(1 U S \$=G H \$ 4.5)$ per plate $(G H \$ 3,6,9$ and 12). Nested logit modelling of the data showed that the highest preference and marginal WTP values were associated with good environmental sanitation, good personal hygiene, natural taste of food, good customer relation, and proximity of vendor, in that order. The study concludes that health consciousness is a major factor that attracts students to vended food. Food vendors should, therefore, improve upon the sanitation of their environments and their personal hygiene to attract and retain customers.
\end{abstract}


Keywords: Food Vending Characteristics, Student Preferences, Willingness to Pay, Discrete Choice Experiment, Nested Logit Model

\section{INTRODUCTION}

Increased urbanization has resulted in an increasingly high proportion of urban food consumers, including students, depending on food vending services to meet their daily nutritional requirements (Food and Agriculture Organisation [FAO], 2007; Muinde \& Kuria, 2005; Rahman, Arif, Bakar \& Tambi 2016; Tabassum \& Rahman, 2012). Food vending services refer to the preparation, sale and consumption of food outside the home (FAO, 2007, Nicolò \& Ag Bendech, 2012). It is estimated that globally, about 2.5 billion people patronise food vending services on a daily basis (FAO, 2007). In Africa, food vending services are springing up rapidly (Esiawonam, 2010; Johnson \& Yawson, 2000; Marras \& Ag Bendech, 2016; Nicolò \& Ag Bendech, 2012), especially around campuses of tertiary institutions (Adam, Hiamey, \& Afenyo, 2014; Opare-Obisaw, 1998). Since most tertiary students, both residential and non-residential, are usually responsible for feeding themselves, they often have to choose between cooking on their own or purchasing food from vendors. However, due to time constraints, difficulties in preparing their own food and easy accessibility of a variety of nutritious food from vendors at a relatively low cost, many tertiary students are prone to the patronage of the services of food vendors (Johnson \& Yawson, 2000; Opare-Obisaw, 1998; Tabassum \& Rahman, 2012). To be able to attract, satisfy and retain the student patrons, food vendors must understand and incorporate their preferences for food vending services in preparing and serving food (Rheinländer, Olsen, Abubakar, Takyi, Konradsen \& Samuelsen, 2008).

The general literature on consumer preferences (desires and/choice) for vended food identifies the underlying attributes of the vending service such as location of the service, serving environment, variety of meals and cost as factors that influence the choice of a vending service (Grüne-Yanoff \& Hansson, 2009; Oni \& Matiza 2014; Tabassum \& Rahman, 2012; Thakkar \& Thatte 2014). Personal hygiene and neatness of food vendors have a strong positive influence on the food preference of consumers (Rheinlander et al., 2008). Neatness is defined by consumers to include the perception of a vendor's decency in physical appearance (Rheilander et al., 2008). The preference of consumers for food vending services is positively associated with the level of environmental cleanliness and sanitation (Fellows \& Hilmi, 2011). Poor environmental sanitation has adverse implications for the health of consumers hence those consumers who are conscious of their health consider good environmental sanitation as important in choosing a food vending service 
(International Food Safety Authorities Network, 2010). Furthermore, food taste is a major characteristic of vended food that determines the preference of consumers for it (Raghunathan, Walker \& Hoyer, 2006). The degree of importance consumers attach to the taste of the food often creates a wide trade-off between taste and consumers' health (Thunström \& Nordström, 2014). Taste of food can be enhanced by the usage of spices, sweetness, salt, fats among others (Thunström \& Nordström, 2014). Environmental sanitation, personal hygiene and taste of food are therefore characteristics of food vending service that directly affect the health of consumers. Besides the health-related characteristics, business and customer-oriented characteristics such as price also affect consumer choices of vended foods (Buttorff, Trujillo, Diez-Canseco, Bernabe-Ortiz \& Miranda, 2015; National Association of Street Vendors of India, 2013). Other essential characteristics of food vending service include easy accessibility, exhibition of local varieties and proximity to the consumer (Ayo, Bonabana-Wabbi \& Serunkuuma, 2012).

In the empirical literature on food vending service, Akerele, Akinbode and Dipeolu (2010); Akinbode, Dipeolu and Okuneye (2011); Alimi, Oyeyinka and Olohungbebe (2016) and Alimi and Workneh (2016) explored consumer willingness to pay for food safety. Franklyn and Badrie (2015); Meysenburg, Julie, Litchfield and RitterGoode (2014) and Lange, Goranzon and Marklinder (2016) examined consumers' knowledge, attitudes and beliefs towards food safety. However, limited research has explored the relationship between vending characteristics and consumers' preferences and willingness to pay for food vending services (Buttorff et al., 2015; Horsu \& Yeboah, 2015). Many of the studies that examined vending characteristics and consumers' preferences for food vending services largely focused on the vendors and only assessed the influence of a single individual service attribute at a time, such as personal hygiene, on consumers' choice decisions (Apanga, Addah, \& Danso, 2014; Mensah, Aidoo \& Teye, 2013; Mensah,Yeboah-Manu, Owusu-Darko \& Ablordey, 2002; Muinde \& Kuria, 2005; Nurudeen, Lawal, \& Ajayi, 2014). These works, therefore, failed to consider how the various factors together comprehensively influence consumers' preferences for food vending services. One other weakness of these studies is that the approaches adopted by them failed to recognise that choice decisions always involve trade-offs between preferences for different characteristics of the service (Lancsar, Fiebig \& Hole, 2017). For instance, consumers may be willing to trade-off business related attributes such as customer relation for healthrelated attributes such as environmental sanitation or to trade-off cost (money) for a healthy meal. Discrete choice experiments (DCEs) are particularly suitable for exploring how a multiplicity of attributes influence consumer's preferences (Lancsar, Fiebig \& Hole, 2017). DCEs are also useful for eliciting trade-offs in preferences for service characteristics. 
DCEs have emerged as an approach in eliciting consumer preferences in various sectors such as transportation and health (Abiiro, Torbica, Kwalamasa \& De Allegri, 2014b, 2016; De Bekker-Grob, Ryan, \& Gerard, 2012), but are rarely applied in eliciting preferences for food vending services especially in sub-Saharan Africa (SSA). The only DCE on food vending services in LMIC context but not within SSA, evaluated consumer preferences for healthy eating from community kitchens in Peru using the best-worst scaling approach (Buttorff et al., 2015). However, the attributes that were covered in the Buttorff et al. (2015)'s DCE were limited to the price (cost) and content-related characteristics of the food (salad, soup, sides, meat and fruit). Other essential attributes that can also influence food choices within LMICs setting such as the vending environment, personal appearance of the vendor, proximity of the vendor and the vendor-customer relations were not captured in the DCE by Buttorff et al. (2015). Besides, none of the studies on food vending services among students adopted the DCE methodology (Ali, Jarrar, Abo-El-Enen, Shamsi \& Ashqar, 2015; Horsu \& Yeboah, 2015; Lange, Goranzon \& Marklinder, 2016; OpareObisaw, 1998).

This study, therefore, explored the characteristics of food vending services that students consider important when deciding to purchase food from vendors, and assessed the relative influence of those characteristics on students' preferences and marginal willingness to pay (mWTP) for vended food, using a DCE. It was hypothesised that students would express significantly higher preferences and willingness to pay for vended food that tastes natural, is less costly, served within an environment with good sanitation, and by vendors that keep good personal hygiene and good customer relation. The remaining sections of the paper present the study methodology, results, discussions and conclusions.

\section{METHODS}

\section{Study Context}

The study was administered to undergraduate students of the Wa Campus of the University for Development Studies (UDS), located in the Wa Municipality of the Upper West Region of Ghana, in the 2016/2017 academic year. The population of undergraduate students on the campus for the 2016/2017 academic year was 9, 394, with males constituting 72.5\% (UDS, 2017). This figure comprises all undergraduate students of the Faculty of Integrated Development Studies (FIDS), Faculty of Planning and Land Management (FPLM), School of Business and Law (SBL) and the Department of Social and Business Education of the Faculty of Education. The Wa Campus commenced operation at the 36-Unit Block in Sombo in 2002 with the 
main campus at Bamahu starting in 2008. The Bamahu Campus currently has five university residential halls. The non-residential students, who are in the majority, reside at diverse locations within the Municipality and commute daily to lectures either by foot, motorbikes or by commercial and private vehicles. The spread of UDS students across the Wa Municipality has contributed to the growing number of food vending services on and around the University Campus and the Wa Municipality at large (Wa Municipal Assembly, 2014).

\section{Study Design}

The study adopted an exploratory sequential mixed methods design within the framework of a DCE (De Bekker-Grob, Ryan, \& Gerard, 2012; Abiiro, Torbica, Kwalamasa \& De Allegri, 2014a). A DCE is a quasi-experimental technique of eliciting stated preferences for products (Johnson, Lancsar, Marshall, Kilambi, Mühlbacher, Regier, Bresnahan, Kanninen \& Bridges, 2013). In a DCE, attributes (the main characteristics of a service or product) are first identified and defined by a number of varied dimensions (attribute levels) (Johnson et al., 2013). A hypothetical choice set is then constructed based on the attributes and their levels and presented to respondents to make a choice (De Bekker-Grob, Ryan, \& Gerard, 2012). The DCE method is rooted in the random utility theory, which postulates that rational consumers are able to estimate the likely outcomes of their decisions and hence will select options that will maximise their satisfaction (Richarme, 2005).

In implementing the exploratory sequential mixed methods design, a qualitative approach was first used to explore the characteristics of food vending services that undergraduate students of UDS consider important when taking decisions to purchase food from vendors (Creswell \& Plano Clark, 2011). The results of this component provided the attributes and attribute levels that informed the design of the quantitative phase. The quantitative component constituted the DCE design and implementation, and the modelling of the DCE data. Hence, this study implemented the typical instrument development variant of the sequential exploratory mixed methods design (Creswell \& Plano Clark, 2011).

\section{The Qualitative Component of the Study}

In line with standard practice, various characteristics (attributes and attribute levels) of food vending services that were initially identified from a literature review were further explored in detail through a qualitative study in May-June, 2016 (Abiiro et al., 2014a; Coast \& Horrocks, 2007; Tetteh, Gyan, Abdallah, Kuunfah \& Ansah, 2016). This was to ensure that the final attributes and their corresponding levels were indeed important to and reflected the peculiar needs of the target 
population (Abiiro et al., 2014a; Coast \& Horrocks, 2007) and well-validated within the study context (Que, Awuah-Offeic, Weidnerd \& Wange, 2017).

A stratified purposive sampling technique was used to select 36 undergraduate UDS students for the study. The main faculties of the Wa Campus were used for stratification. Twelve students, comprising both males and females, residential and non-residential students at various levels of their studies, were purposively selected for each of the three faculty-based Focus Group Discussions (FGDs). An FGD guide, containing topics on background knowledge of respondents on vended foods and the characteristics that affect their choices of food vending services was used to facilitate the process. The FGDs were held in English Language. All discussions were tape-recorded alongside detailed note-taking.

The qualitative data were transcribed and analyzed by three different researchers. Thematic analysis using both deductive and inductive coding was done. A list of 11 attributes were initially identified based on the consensus emerging from the work of the three analysts. The 11 attributes were: taste of food, location of vendor, price, environmental sanitation, variety of meal content, packaging, recognition of vendor by friends, personal hygiene (neatness of vendor), vendor's customer relations, nature of the vending facility and waiting time. After a series of discussions among the researchers, the list was scaled down to six final attributes to reduce cognitive burden. The retained attributes were those considered relevant of informing policy decisions and regarded as more important by the students (Abiiro et al., 2014a). Levels were defined for these attributes based on the data from the FGDs. The information presented in Table 1 includes the six final attributes and their corresponding attribute levels. 
Table 1: Attributes and attribute levels defined for the DCE

\begin{tabular}{|c|c|c|c|c|c|c|}
\hline Attributes & $\begin{array}{l}\text { Attribute- } \\
\text { levels }\end{array}$ & $\begin{array}{l}\text { Description of } \\
\text { attribute levels } \\
\text { from FGDs }\end{array}$ & $\begin{array}{l}\text { Anticipated } \\
\text { utility form }\end{array}$ & $\begin{array}{l}\text { Prior } \\
\text { parameters }\end{array}$ & $\begin{array}{l}\text { Hypothe- } \\
\text { sised } \\
\text { signs }\end{array}$ & $\begin{array}{l}\text { Design } \\
\text { coding }\end{array}$ \\
\hline \multirow[t]{2}{*}{ Taste of food } & Taste spicy & $\begin{array}{l}\text { Food is prepared } \\
\text { with spices }\end{array}$ & \multirow[t]{2}{*}{ Non-linear } & Reference & - & o \\
\hline & $\begin{array}{l}\text { Natural } \\
\text { taste }\end{array}$ & $\begin{array}{l}\text { Food is prepared } \\
\text { with natural flavor }\end{array}$ & & 0.1643 & + & 1 \\
\hline \multirow[t]{2}{*}{$\begin{array}{l}\text { Environmental } \\
\text { sanitation }\end{array}$} & $\begin{array}{l}\text { Poor } \\
\text { sanitation }\end{array}$ & $\begin{array}{l}\text { No hand washing } \\
\text { facilities, drains } \\
\text { unsealed, presence } \\
\text { of flies and rubbish } \\
\text { heaps }\end{array}$ & \multirow[t]{2}{*}{ Non-linear } & Reference & - & o \\
\hline & $\begin{array}{l}\text { Good } \\
\text { sanitation }\end{array}$ & $\begin{array}{l}\text { Hand washing } \\
\text { facilities available, } \\
\text { sealed drains, no } \\
\text { flies and no rubbish } \\
\text { heaps }\end{array}$ & & 0.7700 & + & 1 \\
\hline \multirow[t]{2}{*}{$\begin{array}{l}\text { Personal } \\
\text { hygiene/ } \\
\text { neatness of } \\
\text { vendor }\end{array}$} & $\begin{array}{l}\text { Poor } \\
\text { hygiene }\end{array}$ & $\begin{array}{l}\text { Long and painted } \\
\text { nails, no clean } \\
\text { clothes, no head } \\
\text { gear, no apron }\end{array}$ & \multirow[t]{2}{*}{ Non-linear } & Reference & - & o \\
\hline & $\begin{array}{l}\text { Good } \\
\text { hygiene }\end{array}$ & $\begin{array}{l}\text { Short and clean } \\
\text { nails, clean clothes, } \\
\text { wears apron and } \\
\text { head gear }\end{array}$ & & 0.8294 & + & 1 \\
\hline \multirow[t]{2}{*}{$\begin{array}{l}\text { Vendor's } \\
\text { customer } \\
\text { relations }\end{array}$} & Poor & $\begin{array}{l}\text { The vendor has poor } \\
\text { communication } \\
\text { skills, frowns and } \\
\text { easily gets angry at } \\
\text { customers }\end{array}$ & \multirow[t]{2}{*}{ Non-linear } & Reference & - & o \\
\hline & Good & $\begin{array}{l}\text { The vendor has good } \\
\text { communication } \\
\text { skills, does not } \\
\text { frown and does not } \\
\text { easily get angry at } \\
\text { customers }\end{array}$ & & 0.1505 & + & 1 \\
\hline \multirow[t]{2}{*}{$\begin{array}{l}\text { Location of } \\
\text { vendor }\end{array}$} & Far & $\begin{array}{l}\text { Vehicle is needed } \\
\text { to reach vendor's } \\
\text { location }\end{array}$ & \multirow[t]{2}{*}{ Non-linear } & Reference & - & o \\
\hline & Near & $\begin{array}{l}\text { Vendor is located at } \\
\text { a walking distance }\end{array}$ & & 0.0612 & + & 1 \\
\hline $\begin{array}{l}\text { Cost of } \\
\text { meal in } \mathrm{GH} \phi \\
(1 U S \$=G H \phi 4.5)\end{array}$ & $3,6,9,12$ & $3,6,9,12$ & Linear & -0.0293 & - & $0,1,2,3$ \\
\hline
\end{tabular}

(Source: Field Survey, June, 2016) 


\section{The Quantitative Component}

Using the attributes, attribute levels, prior parameters and design coding illustrated in Table 1, a D-efficient design, for estimating main-effects from a multinomial logit model, with a d-error of 0.10073 , was generated using the Ngene Software (Bliemer \& Collins, 2016). The prior parameters were derived from a pilot DCE, administered to 450 undergraduate students of UDS, by Tetteh et al. (2016), as part of their undergraduate student dissertation. A conditional logit model run on the pilot data produced the coefficients reported in Table 1, as the prior parameters for the main DCE design.

An unlabeled experiment of three choice alternatives, including an opt-out option to avoid stochastic choices (Bahamonde-Birke, Navarro \& Ortúzar, 2017) and to control for the likelihood of over approximation of utility parameters (Hensher, Rose, \& Greene, 2005), was designed. To reduce efficiency losses, the design was a heterogeneous design of 18 choice sets which were randomly blocked into three subdesigns with each block comprising six choice sets ordered differently across blocks (Kessels, 2016). Table 2 presents one of the 18 choice sets as an illustration.

Table 2: An illustration of one of the choice sets

\begin{tabular}{|l|l|l|}
\hline Characteristics & Food vendor A & Food vendor B \\
\hline Taste & The food contains artificial spices & The food has natural flavor \\
\hline Sanitation & $\begin{array}{l}\text { The environment is free from } \\
\text { rubbish and flies, hand washing } \\
\text { facilities are available and drains } \\
\text { are sealed }\end{array}$ & $\begin{array}{l}\text { The environment has rubbish heaps } \\
\text { and flies, no hand washing facilities } \\
\text { and drains are not sealed }\end{array}$ \\
\hline hygiene & $\begin{array}{l}\text { The vendor has long and painted } \\
\text { nails, unclean clothing, no head } \\
\text { gear, no apron }\end{array}$ & $\begin{array}{l}\text { The vendor has short and clean nails, } \\
\text { clean clothing, wears head gear and } \\
\text { apron }\end{array}$ \\
\hline Vendor's customer \\
relation & $\begin{array}{l}\text { The vendor has good } \\
\text { communication skills, does not } \\
\text { frown and does not easily get } \\
\text { angry at customers }\end{array}$ & $\begin{array}{l}\text { The vendor has poor communication } \\
\text { skills, frowns and easily gets angry } \\
\text { at customers }\end{array}$ \\
\hline Location & $\begin{array}{l}\text { A vehicle is required to reach the } \\
\text { location of the vendor }\end{array}$ & $\begin{array}{l}\text { The vendor is located at a walking } \\
\text { distance }\end{array}$ \\
\hline Price & A plate of meal costs GH\$3 & A plate of meal costs GH $\$ 9$ \\
\hline
\end{tabular}

(Source: Authors' construct, May, 2017)

Which of the above food vendors will you prefer to buy from? Vendor A [ ] b. Vendor B [ ] c. Opt-out [ ]

A minimum sample size of 663 was estimated from the $S$-error of 220.87 generated from the D-efficient design. This S-error estimate showed that a minimum sample 
size of 221 respondents per block, resulting in a total sample of 663 respondents was required to statistically estimate all model parameters with adequate precision. The minimum sample size was increased to 670 to cater for potential non-responses.

A multi-stage stratified random sampling technique was used to select the DCE respondents. The student population was first stratified based on the existing faculties of the UDS Wa campus. Each of the strata was further stratified based on departments, undergraduate programmes run and study levels (classes). The distribution of the sample size among the various strata was proportional to the number of students. A simple random sampling technique was used to select the required students from each class. The different blocks and ordering of the choice sets of each block were randomly assigned to the sampled respondents from each class.

The DCE was self-administered through a survey in April-May, 2017. The introductory session of the survey questionnaire contained questions on the socio-economic characteristics of the respondents. The main DCE section had an introduction and the choice sets. The questionnaire was initially pre-tested before the data collection. Only minor changes were made to the context-specific description of the attribute levels within the choice sets after the pre-test. The DCE was manually administered using pen and paper in the English language.

The DCE data were analyzed based on a specified random utility maximization model (McFadden, 1974; Richarme, 2005). Thus; the utility (Ü) of the individual (i) for a choice option (j) in a choice situation (s) is illustrated as:

$U_{i j s}=\beta^{\prime} X_{i j s}+\varepsilon_{i j s}, j=1,2,3 ; s=1,2,3,4,5,6$ .1

Where $X_{i j s}$ is a vector of the relevant attribute level $\mathrm{j}, \beta$ is a vector of the related preference (utility) parameters and $\varepsilon_{i j s}$ is the stochastic error term.

Since the focus of this study was to assess the influence of the attributes and/ attribute levels of the vending service on preferences for the service, a conditional logit (CL) model was first estimated (Louviere, Hensher, \& Swait, 2010; Shi \& Yin, 2018). The conditional logit model fitted to the data failed ( $p>0.05$ ) the Hausman and McFadden specification test of the independence of irrelevant alternatives (Louviere, Hensher, \& Swait, 2010; Daly, Dekker \& Hess, 2016). This was not surprising since the two food vending alternatives (A and B) are naturally similar in characteristics but differ from the opt out alternative.

To partially relax the assumption of independence of irrelevant alternatives, a partially degenerate nested logit (NL) model of two nests, where food vendor A and B 
formed one nest and the opt out, the other, was then estimated (Louviere, Hensher, \& Swait, 2010). The NL model accommodates correlations of the error terms of the similar alternatives (A and B) (Mokhtarian, 2016). The NL utility function is presented as (Newman, Lurkin \& Garrow, 2018):

$U_{i m}=V_{i}+\varepsilon_{m}+\varepsilon$ .2

Where $U_{i m}$ is the total variance associated with each alternative in nest $\mathrm{m}, V_{i}$ is the observed component, $\varepsilon_{m}$ is the common error term, and $\varepsilon_{i}$ is an independent error term.

Relying on the NL model for our estimation, we modelled the probability (P) of an individual (i)'s choice of an alternative $j$ within nest $g$ as a function of the probability of alternative $j$ coming from nest $g$ and the probability of alternative $j$ from nest $g$ being chosen, given that nest g was chosen (Ryan, Skåtun \& Major, 2008).

$P j(g) i=P($ nest $g) . P(j$, given nest $g)$. 3

The utility of an individual (Û) who makes a choice was then modelled as follows:

$\mathrm{U}_{i}=B_{0}+\beta_{1}$ (natural taste $)+\beta_{2}($ good sanitation $)+\beta_{3}($ good personal hygiene $)+\beta_{4}($ good

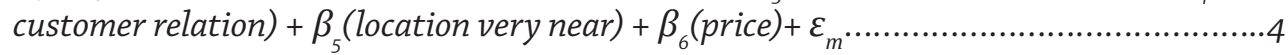

Where $B_{o}$ is the constant, $\beta_{1}$ to $\beta_{6}$ represent the coefficients (utilities) of the various attribute levels in a given choice set and $\varepsilon_{m}$ represents the stochastic error term.

To avoid confounding with the constant, all attributes levels except the price attribute were effects-coded for the analysis (Daly, Dekker \& Hess, 2016). Robust standard errors were estimated by clustering at the individual level to account for intra-respondent correlation. Using the price (cost) attribute (coded continuous) as the dependent variable, mWTP values for each food vending characteristic were estimated from the NL model, within a confidence interval (CI) of $95 \%$ using the well-known DELTA method that requires relatively lower computational time (Koopman, 2016). The mWTP values were estimated as the marginal rate of substitution between each attribute $\mathrm{X}^{\mathrm{k}}$ and the cost (C) attribute as mathematically illustrated below (Lancsar, Fiebig \& Hole, 2017):

$\operatorname{mWTP}_{\mathrm{x}}{ }^{\mathrm{k}}=-\mathrm{MU}_{\mathrm{x}}{ }^{\mathrm{k}} / \mathrm{MU}_{\mathrm{C}}$ .5

where $\mathrm{MU}_{\mathrm{x}}{ }^{\mathrm{k}}$ is the marginal utility (coefficients) of the attribute level $\mathrm{X}^{\mathrm{k}}$ and MUc is the marginal utility (coefficient) of the cost attribute.

The relative importance of each of the attributes was estimated using the partial log likelihood estimation approach to determine the overall contribution of each 
of the attributes to the explanatory power of the NL model (Lancsar, Louviere \& Flynn, 2007). The theoretical validity of each estimated parameter was examined by comparing the estimated sign of its coefficient to the expected sign. All analyses were done using Stata 12 software.

\section{RESULTS}

\section{Respondents Characteristics}

A total of 670 DCE questionnaires were successfully distributed to students, out of which 585 completed questionnaires were returned, representing a response rate of $87 \%$. Table 3 illustrates some of the basic characteristics of the respondents. The majority (62.39\%) of the respondents were males; $75.66 \%$ of them lived off the University Campus; and $54.36 \%$ of them cooked alone at their places of residence. Only $25.5 \%$ of them often purchased food from vendors but the rest rarely (58\%) or never (16.9\%) purchased food from vendors within the Wa Municipality.

Table 3: Basic characteristics of the respondents

\begin{tabular}{|c|c|c|c|}
\hline Variable & Categories & Number of respondents & Percentage \\
\hline \multirow[t]{2}{*}{ Sex } & Male & 365 & 62.4 \\
\hline & Female & 220 & 37.6 \\
\hline \multirow[t]{4}{*}{ Faculty } & Integrated Development Studies & 190 & 32.5 \\
\hline & Planning and Land Management & 157 & 26.8 \\
\hline & Business and Law & 175 & 29.9 \\
\hline & Education & 63 & 10.8 \\
\hline \multirow[t]{4}{*}{ Year (level) of study } & Level 100 & 117 & 20.0 \\
\hline & Level 200 & 149 & $25 \cdot 5$ \\
\hline & Level 300 & 159 & 27.2 \\
\hline & Level 400 & 160 & 27.4 \\
\hline \multirow[t]{2}{*}{ Place of residence } & Off-campus & 442 & $75 \cdot 7$ \\
\hline & On-campus & 143 & 24.4 \\
\hline \multirow{2}{*}{$\begin{array}{l}\text { Cooking } \\
\text { arrangements }\end{array}$} & Cook alone & 318 & 54.4 \\
\hline & Cook with colleague(s) & 267 & 45.6 \\
\hline \multirow{3}{*}{$\begin{array}{l}\text { Frequency of use of } \\
\text { vendor }\end{array}$} & Never & 99 & 16.9 \\
\hline & Rarely & 339 & 58.0 \\
\hline & Often & 147 & 25.1 \\
\hline Total & & 585 & 100 \\
\hline
\end{tabular}

(Source: Field Survey, May, 2017) 


\section{Estimated Average Preferences and $m W T P$ for the Characteristics of Food Vending Service}

Each valid DCE response produced three observations. Since each respondent was presented with six choice sets, 18 observations were therefore associated with each respondent who successfully completed all six choice questions. The 585 respondents produced 3,510 valid responses, providing 10,530 observations for analysis. In all, 173 (29.57\%) respondents chose food vendor "A", 164 (28.03) chose food vendor B and 248 respondents (42.39) opted out.

Table 4 presents the results of the two models used to estimate average preferences for each attribute level of food vending service. Model 1 is the conditional logit (CL) model and model 2 is the nested logit (NL) model. Although both models were overall statistically significant ( $p<0.01$ ), the failure of the Independence of Irrelevance Alternatives ( $p<0.05$ ) test by the CL model implied that it could not be relied upon. Besides, the NL model produced a relatively better explanatory power (Log pseudo likelihood $=-3667.7758)$ than the CL model (Log pseudo likelihood= - 3678.1609). Furthermore, since the dissimilarity index of the NL model (0.3407) fell between zero and one and was statistically significant at the 95\% CI level, it is confirmed that the NL model was statistically significantly different from the CL model (Cameron, 2010). The results and discussions were, therefore, based on the NL model estimation.

The results showed that overall, there was no statistically significant difference in preference for the services of a food vendor compared to cooking at home (optout) as illustrated by the $\mathrm{p}$-value of the constant term $(\mathrm{p}=0.062)$. However, each of the attribute levels of the food vending service statistically significantly ( $p<0.01$ ) influenced students' preferences for the services of a food vendor. As shown in Table 4, the regression coefficients of all the explanatory variables were associated with their expected signs, thereby confirming the theoretical validity of the estimated parameters. 
Table 4: Estimated average preferences for the attribute levels of food vending service

\begin{tabular}{|c|c|c|c|c|}
\hline \multirow[t]{2}{*}{ Attribute-level } & \multicolumn{2}{|c|}{ Model 1 Conditional logit } & \multicolumn{2}{|c|}{ Model 2: Nest logit } \\
\hline & $\beta$ & p-value & $B$ & P-value (95\% CI) \\
\hline Natural taste & 0.21 & $<0.001$ & 0.25 & $<0.001$ \\
\hline Good environmental sanitation & 0.26 & $<0.001$ & 0.47 & $<0.001$ \\
\hline Good personal hygiene & 0.18 & $<0.001$ & 0.37 & $<0.001$ \\
\hline Good customer relations & 0.15 & $<0.001$ & 0.18 & $<0.001$ \\
\hline Location near & 0.07 & 0.002 & 0.07 & 0.004 \\
\hline Price & -0.05 & $<0.001$ & -0.04 & $<0.001$ \\
\hline Constant_A & -0.07 & 0.252 & \multirow[t]{2}{*}{0.15} & \multirow[t]{2}{*}{0.062} \\
\hline Constant_B & -0.13 & 0.050 & & \\
\hline $\begin{array}{l}\text { Dissimilarity index (non- } \\
\text { degenerate nest) }\end{array}$ & - & - & 0.34 & $\begin{array}{l}(C I=0.1811- \\
0.5003)\end{array}$ \\
\hline Number of Observations & \multicolumn{2}{|l|}{10530} & \multicolumn{2}{|l|}{10530} \\
\hline Number of cases & \multicolumn{2}{|l|}{3510} & \multicolumn{2}{|l|}{3510} \\
\hline Wald chi2(6) & \multicolumn{2}{|l|}{217.09} & \multicolumn{2}{|l|}{$143 \cdot 37$} \\
\hline Prob $>$ chi $^{2}$ & \multicolumn{2}{|l|}{0.0000} & \multicolumn{2}{|l|}{0.000} \\
\hline Log pseudo likelihood & \multicolumn{2}{|l|}{-3678.16} & \multicolumn{2}{|c|}{-3667.78} \\
\hline
\end{tabular}

(Source: Field Survey, May, 2017)

Table 5 reports the results of the mWTP estimation for each of the attribute levels of food vending service in both Ghana cedis and US dollar equivalence ( $1 \mathrm{US} \$=\mathrm{GH} \$ 4.5$ ). The results showed that other things being equal, students were willing to pay the highest price of GH\$12.22 for a plate of food served at a vending environment with good sanitation (mWTP= GH\$12.22; 95\% CI= GH 1 19.09-5.34); GH\$9.58 for a plate of meal if the vendor practices good personal hygiene (mWTP=GH $\$ 9.58 ; 95 \% \mathrm{CI}=\mathrm{GH} \phi$ 15.25-3.91); GH $\$ 6.41$ if the food tastes natural (mWTP= GH $\$ 6.41 ; 95 \% \mathrm{CI}=\mathrm{GH} \$ 9.60-$ 3.21); GH $\$ 4.70$ if the vendor has good customer relations (mWTP= GH $\$ 4.70 ; 95 \% \mathrm{CI}=$ $\mathrm{GH} \$ 7.15-2.25$ ) and a lowest price of GH\$1.9 for a plate of food if the vendor is located nearer to the student (mWTP= GH $\$ 1.9 ; 95 \% \mathrm{CI}=\mathrm{GH} \$ 3.36-0.49)$. 
Table 5: mWTP estimates for the attribute levels

\begin{tabular}{|l|l|l|l|}
\hline Attribute levels & $m W T P(G H \phi)$ & $95 \%$ confidence interval $(C I)$ & Rank \\
\hline $\begin{array}{l}\text { Good environmental } \\
\text { sanitation }\end{array}$ & $12.22(U S \$ 2.72)$ & $19.09-5.34$ & $1 s t$ \\
\hline Good personal hygiene & $9.58(U S \$ 2.13)$ & $15.25-3.91$ & $2 n d$ \\
\hline Natural taste & $6.41(U S \$ 1.42)$ & $9.60-3.21$ & 3 rd \\
\hline Good customer relations & $4.70(U S \$ 1.04)$ & $7.15-2.25$ & 4 th \\
\hline Location near & $1.90(U S \$ 0.42)$ & $3.36-0.49$ & 5 th \\
\hline
\end{tabular}

(Source: Field Survey, May, 2017)

In terms of the overall influence of each attribute over consumer preferences, the partial log likelihood estimation presented in Table 6, revealed the order of importance of the attributes as: taste of food, environmental sanitation, customer relations, personal hygiene of vendor, price per plate of a meal and lastly distance to the vendor.

Table 6: Relative importance of attributes using the partial log likelihood method

\begin{tabular}{|l|l|l|l|l|l|}
\hline Attribute & $\begin{array}{l}\text { Loglikelihood } \\
\text { (attribute } \\
\text { excluded) }\end{array}$ & $\begin{array}{l}\text { Partial } \\
\text { effect- } \\
\text { change } \\
\text { in log- } \\
\text { likelihood }\end{array}$ & $\begin{array}{l}\text { Relative } \\
\text { effect- } \\
\text { change in log } \\
- \text { likelihood }\end{array}$ & $\begin{array}{l}\text { Cumulative } \\
\text { relative } \\
\text { change }\end{array}$ & $\begin{array}{l}\text { Order of } \\
\text { importance }\end{array}$ \\
\hline Full model & -3667.8 & - & - & - & - \\
\hline Taste of food & -3717.2 & 49.4 & 0.33 & 0.33 & 1 \\
\hline $\begin{array}{l}\text { Environmental } \\
\text { sanitation }\end{array}$ & -3702.7 & 34.9 & 0.23 & 0.56 & 2 \\
\hline $\begin{array}{l}\text { Customer } \\
\text { relations }\end{array}$ & -3693.5 & 25.7 & 0.17 & 0.73 & 3 \\
\hline Personal hygiene & -3692.7 & 24.9 & 0.16 & 0.89 & 4 \\
\hline Price per plate & -3679.5 & 11.7 & 0.077 & 0.97 & 5 \\
\hline $\begin{array}{l}\text { Location of } \\
\text { vendor }\end{array}$ & -3672.5 & 4.7 & 0.03 & 6 \\
\hline
\end{tabular}

(Source: Field Survey, May, 2017) 


\section{DISCUSSION}

The DCE results revealed that there was no statistically significant difference in student preferences for the services of food vendors compared to the students preparing and consuming their own food at home. This implies that the students do not necessarily mind where they get their meals from provided they promote good health. Given that the majority of the respondents rarely (58\%) or never (16.92\%) purchased food from vendors, a lot of efforts are required by food vendors to attract such students to vended food. Food vendors, therefore, need to understand the food vending characteristics, and the broader socio-economic and cultural factors, that influence students' decisions to purchase food from vendors and ensure that such issues are given serious consideration during food vending. Our study has demonstrated that the nature of the vending service and its characteristics influenced students' choices between vended food and their own prepared meals. Further studies are needed to understand the broader socio-economic and cultural factors that affect students' patronage of food vending services. Our study results confirm the findings of other studies (Buttorff et al, 2015; Oni \& Matiza, 2014; Tabassum \& Rahman, 2012; Thakkar \& Thatte, 2014) that food vending service characteristics including taste, environmental sanitation, customer relations, location of the vendor and price of the meal significantly influenced consumer preferences for food vending services. However, in terms of relative importance of the attribute levels to the students, it was clear that students were willing to pay the highest price for those attribute levels that had positive implication for the promotion of health. These included good environmental sanitation, good personal hygiene of the vendor and natural taste of food.

Good environmental sanitation was associated with the highest mWTP value. This is in line with previous non-DCE studies showing that environmental cleanliness was an important factor influencing consumer food preferences and WTP for foodrelated attributes (Alimi, Oyeyinka, \& Olohungbebe, 2016; Alimi \& Workneh, 2016; Fellows \& Hilmi, 2011). Poor environmental sanitation has adverse implications for the health of consumers, and hence those consumers who are conscious of the health implications of the food they consume will always consider it very important in choosing a food vending service (Akinbode, Dipeolu \& Okuneye 2011; Alimi, Oyeyinka, \& Olohungbebe, 2016; Alimi \& Workneh, 2016; International Food Safety Authorities Network, 2010; Owusu-Sekyere, Owusu, \& Jordaan, 2014). The study argues in line with other studies that the evidence of high students' preferences for good environmental sanitation within the vended environment could be a reflection of the poor attention food vendors often pay to sanitation practices within their 
vending sites (Alimi, Oyeyinka, \& Olohungbebe, 2016; Alimi \& Workneh, 2016; Chukuezi, 2010; Muinde \& Kuria, 2005; Muyanja, 2011; Okojie \& Isah, 2014).

Another attribute that has implications for the health of consumers and was also highly valued is good personal hygiene or cleanness of the vendor. In the qualitative part of the study, students expressed their dislike for vendors who dress shabbily, have long nails and do not wear head gears and aprons. This was further confirmed by our DCE findings and in line with the findings of other previous studies (Alimi \& Workneh, 2016; Benny-Olivierra \& Badrie, 2007; Fellows \& Hilmi, 2011; Rheinlander et al., 2008). The importance of this attribute to consumers in general emanates from the vast evidence of poor personal hygiene practices including handling of money while serving food, wearing of big sized and multiple rings, not wearing aprons and hair cover and keeping long and unclean finger nails, among food vendors in developing countries (Alimi \& Workneh, 2016; Cortese, Veiros, Feldman \& Cavalli, 2015; Franklyn \& Badrie, 2015). The relatively high preference for a vendor that practices personal hygiene signifies the desire of the students for a guaranteed safety. More so, there is evidence linking fecal-oral transmission of diseases to the personal hygiene of food vendors (Alimi \& Workneh, 2016; Ayeh-Kumi, Quarcoo, Kwakye-Nuako, Kretchy, Osafo-Kantanka, \& Mortu, 2014).

The study results showed that natural taste as an attribute level was the third most important in terms of mWTP values. However, as an attribute, taste had the highest influence over students' preferences for a particular vendor. This is plausibly due to the fact that consumers often associate taste with nutrition and hence it is an attribute that can enhance their health and wellbeing (Raghunathan, Walker \& Hoyer, 2006; Thunströma \& Nordströmb, 2014). Another plausible explanation of this finding is that within the Wa Municipality, most of the meals that were served were traditional staples of Ghana (Laryea, Esther, Ibok \& William, 2016). Traditionally, such meals are usually prepared without artificial spices and hence consumers including students have become addicted to the natural taste of the meals. The students, therefore, showed less preferences for the vended food if the taste of that food is enhanced by artificial spices including maggi, colouring and fats. It is reported that some of these spices and food preservatives contain substances that pose serious threats to the health of consumers (Alimi \& Workneh, 2016).

The business and customer-oriented attribute levels though also statistically significantly influenced preferences for the food vending services; they were associated with relatively lower mWTP values compared to the health-related food vending characteristics. This does not imply that such attributes were not important to the students but rather students were implicitly expressing their 
willingness to trade-off those cost (price) and time (distance) related attributes in favor of the health-related attributes. The study results therefore suggest that students were likely to give relatively less attention to other very important attribute levels such as good customer relations, proximity of the vendor and cost of the service as long as they were assured of good sanitation, natural taste of food and good personal hygiene practices of the vendor. However, considering the results of the partial log likelihood estimation, it was realised that the overall influence of customer relationship was even greater than personal hygiene practice as attributes. Hence, there is the need to also pay serious attention to enforcing good customer relationship among food vendors.

The application of this DCE to elicit students' preferences for food vending in SSA has methodological relevance and weaknesses. Building the DCE on attributes and attribute levels derived from a qualitative study contributes to improving the content validity of the results (Abiiro et al., 2014a; Mangham, Hanson \& McPake, 2009; Que et al., 2017). Going beyond presenting estimated model coefficients to providing mWTP estimates using a post-estimation procedure that produced tradeoffs between the price attribute and each of the other attribute levels enhanced an easy appreciation of the relative importance of each of the vending characteristics (Lancsar, Fiebig \& Hole, 2017). Notwithstanding these strengths, as a crosssectional hypothetical experiment among students of one university campus, the elicited preferences described in this study may differ across other universities (locations) and the general population at large. Therefore, even though the results are internally valid, generalizability beyond the study context cannot be obviously guaranteed (Louviere, Hensher, \& Swait, 2010). The 13\% of the sampled respondents who did not return their questionnaires were mainly from SBL. This could have affected the proportionate representativeness of the final sample. However, given that our D-efficient design and our research questions required the estimation of main effects (average preferences) alone, variation in respondents' characteristics could not have seriously affected the analysis (Lancsar, Fiebig \& Hole, 2017). Despite the reduction in sample size due to non-response, all the estimated coefficients of the attribute levels were statistically significant $(p<0.01)$. Those who failed to return the questionnaires were contacted on three different occasions but they still refused to respond.

\section{CONCLUSION}

The DCE revealed relatively higher marginal willingness to pay values for those food vending characteristics that directly affect the health of consumers. These include: good environmental sanitation, good personal hygiene of the vendor and 
natural taste of food. This implies that the students were conscious of the health implications of food vending services, hence were implicitly willing to trade-off other food vending characteristics for a guaranteed health safety with food vending services. If their safety is guaranteed, the students will now shift their focus to vendors whose customer relationship is good before considering the cost (price) and time (distance) related characteristics of the vending service. The study therefore recommends that food vendors should first aim at ensuring the health safety of their consumers by locating their services in clean environments (free from rubbish and flies, with hand washing facilities available and drains sealed) accompanied with regular cleaning of the vending sites. Vendors should also reduce the content of artificial spices such as maggi, colouring and fats in meals in order to keep the taste natural, and ensure that they appear neat (keep short and clean nails, clean clothing, wear head gear and apron) when serving meals as well as enforce good customer relationship by being polite and friendly to their customers. School authorities and the Municipal Assembly should ensure the licensing and monitoring of vendors that operate around the University Campus in particular and that of Wa township at large, to ensure that regulations and bye-laws concerning food vending are strictly adhered to.

\section{ACKNOWLEDGEMENTS}

We are very grateful to Tetteh Nathan, Abdallah Kaamah Faisal, Kuufah Nang James and Kelvin Owusu Ansah, who contributed to the design and implementation of the pilot phase of this study.

\section{REFERENCES}

Abiiro, G.A., Torbica, A., Kwalamasa, K. and De Allegri, M. (2014b). Eliciting community preferences for complementary micro health insurance: A discrete choice experiment in rural Malawi. Social Science \& Medicine, 120, pp. 160-168.

Abiiro, G.A., Torbica, A., Kwalamasa, K. and De Allegri, M. (2016). What factors drive heterogeneity of preferences for micro-health insurance in rural Malawi?. Health Policy and Planning, 31, pp. 1172-1183.

Abiiro,G.A., Leppert, G.B., Mbera, G., Robyn, P.J. and De Allegri, M. (2014a). Developing attributes and attribute-levels for a discrete choice experiment on micro health insurance in rural Malawi. BMC Health Service Research, 14 (235), pp.1-15.

Adam, I., Hiamey, S.E. and Afenyo, E.F. (2014). Students' food safety concerns and choice of eating place in Ghana. Food Control, 43, pp.135-141. 
Akerele, D., Akinbode, S.O. and Dipeolu, A.O. (2010). Willingness to pay for the safety of Kilishi in Sokoto, Nigeria. Journal of Agricutural and Food Information, 11, pp. 330-339.

Akinbode, S.O., Dipeolu, A.O. and Okuneye, P.A. (2011). Willingness to pay for street food safety in Ogun State, Nigeria. Journal of Agricultural and Food Information, 12, pp. 154-166.

Ali, H.I., Jarrar, A.H., Abo-El-Enen, M, Shamsi, M.A. and Ashqar H. (2015). Students' perspectives on promoting healthful food choices from campus vending machines: A qualitative interview study. BMC Public Health, 15 (512), pp.1-8.

Alimi, B.A., Oyeyinka, A.T. and Olohungbebe, L.O.(2016). Socioeconomic characteristics and willingness of consumers to pay for the safety of fura de nunu in Ilorin, Nigeria. Quality Assurance and Safety of Crops and Foods, 8 (1), pp. 81 - 86.

Alimi, B.A. and Workneh, T.S. (2016). Consumer awareness and willingness to pay for saftety of street foods in developing countries: A review. International Journal of Consumer Studies, 40, pp. 242-248.

Apanga, S., Addah, J. and Danso R.S. (2014). Food safety knowledge and practice of street food vendors in rural northern Ghana. Food and Public Health, 4(3), pp. 99-103.

Ayeh-Kumi, P.F., Quarcoo, S., Kwakye-Nuako, G., Kretchy, J.P., Osafo-Kantanka, A. and Mortu, S. (2009). Prevalence of intestinal parasitic infections among food vendors in Accra, Ghana. Journal of Tropical Medicine and Parasitology, 32, pp. $1-8$.

Ayo, S.A., Bonabana-Wabbi, J. and Serunkuuma, D. (2012). Determinants of fast food consumption in Kampala, Uganda. African Journal of Food, Agriculture, Nutrition and Development, 12(5), pp. 6567-6576.

Bahamonde-Birke, F.J., Navarro, I. and Ortúzar, J.D. (2017). If you choose not to decide, you still have made a choice. Journal of Choice Modelling, 22, pp. 13-23.

Benny-Olivierra,C. and Badrie, N. (2007). Hygienic practices by vendors of the street food "doubles" and the public perception of vending practices in Trinidad, West Indies. Journal of Food Safety, 27(1), pp. 66-81.

Bliemer, M.C.J. and Collins, A.T. (2016). On determining priors for the generation of efficient stated choice experimental designs. Journal of Choice Modelling, 21, pp. 10-14.

Buttorff, C., Trujillo, A.J., Diez-Canseco F., Bernabe-Ortiz A. and Miranda J.J. (2015). Evaluating consumer preferences for healthy eating from community kitchens 
in low-income urban areas: A discrete choice experiment of Comedores Populares in Peru. Social Science \& medicine, 140, pp. 1-8.

Cameron, A.C. (2010). Microeconometrics using stata. Texas: Stata Press, College Station.

Chukuezi, C.O. (2010). Food safety and hygienic practices of street food vendors in Owerri, Nigeria. Studies in Sociology of Science, 1(1), pp. 50-57.

Coast, J. and Horrocks, S.A. (2007). Developing attributes and levels for discrete choice experiments using qualitative methods. Journal of Health Services Research \& Policy, 12, pp. 25-30.

Cortese, R.D.M., Veiros, M.B., Feldman, C. and Cavalli, S.B. (2015). Food safety and hygiene practices of vendors during the chain of street food production in Florianopolis, Brazil: A cross-sectional study. Food Control, 62, pp. 178-186.

Creswell, J. W. and Plano Clark, V. L. (2011). Designing and Conducting Mixed Methods Research (2nd ed.) Thousand Oaks: SAGE Publications.

Daly, A., Dekker, T. and Hess, S. (2016). Dummy coding vs effects coding for categorical variables: Clarifications and extensions. Journal of Choice Modelling, 21, pp. 3641.

De Bekker-Grob, E.W., Ryan, M. and Gerard K. (2012). Discrete choice experiment in health economics: A review of literature. Health Economics, 21, pp. 145-172.

Esiawonam, D.B. (2010). Small-Scale Business: A case study of stagnation among street food vendors in Accra. Accra: Ashesi University College.

FAO, (2007). Spotlight: School children, street food and micronutrient Deficiencies in Tanzania. Rome: Food and Agricultural Organization.

Fellows, P. and Helmi, M. (2011). Selling street foods and snacks. Food and Agriculture Organisation, Rural Infrastructure and agro industries division. Rome: United Nations Organisation.

Franklyn, S. and Badrie, N. (2015). Vendor hygienic practices and consumer perception of food safety during the Carnival festival on the Island of Tobago, West Indies. International Journal of Consumer Studies, 39(2), pp. 145-154.

Ghana Statistical Service, (2010). Population and housing census report:summary report of final results, Accra, Ghana: Ghana Statistical Service.

Grune-Yanoff, T. and Hansson, S.O. (Eds.) (2009). Preferences Change: Approaches from Philosophy, Economics and Psychology. Springer, Dordrecht. Theory and Decision Library A, 42, pp. 1-26. 
Hensher, D.A., Rose, J.M. and Greene, W.H. (2005). Applied Choice Analysis. Cambridge: University Press.

Horsu, E.N. and Yeboah, S.T. (2015). Consumer perception and preference of fast food: A study of tertiary students in Ghana. Science Journal of Business and Management, 3(1): pp. 43-49.

International Food Safety Authorities Network, (2010). Basic steps to improve safety of street-vended food. Information Note3, (online) Available at: https://www.who. int/foodsafety/fs_management/No_03_StreetFood_Jun10_en.pdf?ua=1. Accessed on $7^{\text {th }}$ February, 2019.

Johnson, R.F., Lancsar, E., Marshall, D., Kilambi, V., Mühlbacher, A., Regier, D.A., Bresnahan, B. W., Kanninen, B. and Bridges, J.F.P. (2013). Constructing experimental designs for discrete-choice experiments: Report of the ISPOR conjoint analysis experimental design good research practices task force. Value in Health, 16(1), pp. 3-13.

Johnson,P.N.T. and Yawson, R.M. (2000). Enhancing the food security of the peri-urban and urban poor through improvements to the quality, safety and economics of streetvended foods in Accra. A report on workshop for stakeholders, policy makers and regulators of street-food vending. Accra, Ghana: Food Research Institute (CSIR).

Kessels, R. (2016). Homogeneous versus heterogeneous designs for stated choice experiments: Ain't homogeneous designs all bad? Journal of Choice Modelling, 21, pp. 2-9.

Koopman, L. (2016). Comparing the delta method, individual level bootstrap, and cluster level bootstrap to compute standard errors of two-level scalability coefficients a simulation study. Master thesis. Leiden: Mathematical Institute, Leiden University.

Lancsar, E., Louviere, J. and Flynn, T. (2007). Several methods to investigate relative attribute impact in stated preference experiments. Social Science \& Medicine 64(8), pp. 1738-1753.

Lancsar, E., Fiebig, D.G. and Hole, A.R. (2017). Discrete choice experiments: A guide to model specification, estimation and software. Pharmacoeconomic, 35, pp. $697-716$.

Lange, M.,Goranzon, H. and Marklinder H. (2016). Self-reported food safetyknowledge and behaviour among home and consumer studies students. Food Control, 67, pp. 265-272.

Laryea, D., Esther, Y.A., Ibok, O. and William, O.A. (2016). Consumer perception of traditional foods in Ghana: A case-study in Kumasi and Sekondi. Nutrition \& Food, 46(1), pp. 96-107. 
Louviere, J.J., Hensher, D.A. and Swait, J.D. (2010). Stated choice methods: Analysis and applications. Cambridge: University Press.

Mangham, L.J, Hanson, K. and McPake, B. (2009). How to do(or not to do)... Designing a discrete choice experiment for application in a low-income country. Health Policy and Planning, 24, pp. 151-158.

Marras S. and Ag Bendech, M. (2016). Street food in urban Ghana: A desktop review and analysis of findings and recommendations from existing literature. Accra: Food and Agricultural Organization.

McFadden, D. (1974). Conditional logit analysis of qualitative choice behaviour. In: Zarembka, P. (Ed.), Frontiers in Econometrics. Academic Press, New York, pp. 105-142.

Mensah, J.O., Aidoo, R. and Teye, A.N. (2013). Analysis of street food consumption across various income groups in the Kumasi Metropolis of Ghana. International Review of Management and Business Research, 2, pp.951-961.

Mensah, P., Yeboah-Manu, D., Owusu-Darko, K. and Ablordey A., (2002). Streets foods in Accra, Ghana: how safe are they? Bulletin of the World Health Organisation, 8o(7), pp. 546-554.

Meysenburg, R., Julie A., Litchfield, R.A. and Ritter-Gooder, P.K. (2014). Food safety knowledge, practices and beliefs of primary food preparers in families with young children. A mixed methods study. Apetite, 73, pp. 121-131.

Mokhtarian, P.L. (2016). Presenting the independence of irrelevant alternatives property in a first course on logit modeling. Journal of Choice Modelling, 21, pp. 25-29.

Muinde, O.Kand Kuria., E., (2005). Hygienic and sanitary practices of vendors of street foods in Nairobi, Kenyah. African Journal of Food Agriculture and Nutritional Development(AJFAND), 5, pp. 1-15.

Muyanja, C., Nayiga, L., Brenda, N. and Nasinyama, G. (2011). Practices, knowledge and risk factors of street food vendors in Uganda. Food Control, 22, pp. 15511558.

National Association of Street Vendors of India (2013). Sustaining food security from the streets Mass training of street food vendors on food safety and hygiene. India: National Association of Street Vendors of India.

Newman, J.P., Lurkin, V. and Garrow, L.A. (2018). Computational methods for estimating multinomial, nested, and cross-nested logit models that account for semi-aggregate data. Journal of Choice Modelling, 26, pp. 28-40. 
Nicolò, G. and Ag Bendech M. (2012). Street Food Vending in West African Cities (Mali, Cote d'Ivoire, Sierra Leone, Ghana) - Potential and Challenges. Accra: Food and Agricultural Organization.

Nurudeen, A.A., Lawal, A.O. and Ajayi, S.A. (2014). A survey of hygiene and sanitary practices of street food vendors in the Central State of Northern Nigeria. Journal of Public Health and Epidemiology, 6, pp. 174-181.

Okojie, P.W. and Isah, E.C. (2014). Sanitary conditions of food vending sites and food handling practices of street food vendors in Benin City, Nigeria: Implication for food hygiene and safety. Journal of Environmental and Public Health, 6. Available at: http://dx.doi.org/10.1155/2014/701316. Accessed on $7^{\text {th }}$ February, 2019.

Oni, O.A. and Matiza T. (2014). Factors influencing consumer choice of fast food outlet: The case of an American fast food franchise brand operating in a predominantly rural community. Mediterranean Journal of Social Sciences, 5(20), pp.802-808.

Opare-Obisaw, C. (1998). Students' patronage and views on the operations and services of food vendors. Journal of Consumer Studies \& Home Economics, 22 , pp.139-146.

Owusu-Sekyere, E., Owusu, V. and Jordaan, H. (2014). Consumer preferences and willingness to pay for beef food safety assurance labels in the Kumasi Metropolis and Sunyani Municipality of Ghana. Food Control, 46, pp. 152-159.

Que, S., Awuah-Offeic, K., Weidnerd, N. and Wange, Y. (2017). Discrete choice experiment validation: A resource project case study. Journal of Choice Modelling, 22, pp. 39-50.

Raghunathan, R., Walker, N.R. and Hoyer, W.D. (2006). The unhealthy tasty intuition and its effects on taste inferences, enjoyment, and choice of food products. Journal of Marketing, 70(4), pp. 170-184.

Rahman, M.M., Arif, M.T., Bakar, K. and Tambi, Z.B. (2016). Food safety knowledge, attitude and hygiene practices among the street food vendors in Northern Kuching city, Sarawak. Borneo. Science, 31, pp. 95-103.

Rheinländer, T., Olsen, M., Abubakar B.J., Takyi, H., Konradsen, F. and Samuelsen, H. (2008). Keeping up appearances: perceptions of street food safety in urban Kumasi, Ghana. Journal of Urban Health, 85(6), pp. 952-964.

Richarme, M. (2005). Consumer Decision Making models strategies and theories. USA: Decision Analyst.

Ryan, M., Skåtun, D. and Major, K. (2008). Using discrete choice experiments to go beyond clinical outcomes when evaluating clinical practice. In: Ryan, M., 
Gerard, K., Amaya-Amaya, M. (Ed.), Using discrete choice experiments to value health and health care. The Economics of Non-Market Goods and Resources, pp.101116. Dordrecht: Springer.

Shi, H. and Yin, G. (2018). Boosting conditional logit model. Journal of Choice Modelling, 26, pp. 48-63.

Tabassum, A. and Rahman, T. (2012). Differences in consumer attitude towards selective fast food restaurants in Bangladesh: An implication of multi-attribute model. World Review of Business Research, 2(3), pp. 12-27.

Tetteh, N., Gyan, K.E., Abdallah, K.F., Kuunfah, N.J. and Ansah, K.O, (2016). Assessing students' preferences for food vending services: A discrete choice experiment at the University for Development Studies. Undergraduate student dissertation. Tamale, Ghana: University for Development Studies.

Thakkar, K. and Thatte, M.R. (2014). Consumer perceptions of food franchise: A study of McDonalds and KFC. International Journal of Scientific and Research Publications, 4(3), pp. 1-5.

Thunström L., and Nordström J. (2014). The importance of taste for food demand and the experienced taste effect of healthy labels - An experiment on potato chips and bread. Sweden: Department of Economics, Lund University.

UDS (2017). Vice-chancellor's report: $18^{\text {th }}$ Congregation. Tamale, Ghana: University for Development Studies.

Wa Municipal Assembly (2014). District Medium Term Development Plan 2014-2017. Wa, Ghana: Wa Municipal Assembly. 